\title{
Buyer-Supplier Contract Length and the Innovation of Supplier Firms
}

\author{
Nguyen Thanh Liem ${ }^{1,2, * \mathbb{C}}$, Nguyen Vinh Khuong $2,3, * \mathbb{C}$ and Nguyen Thi Canh ${ }^{2,4}(\mathbb{C}$ \\ 1 Faculty of Banking \& Finance, University of Economics and Law, Ho Chi Minh City, Vietnam \\ 2 Vietnam National University, Ho Chi Minh City, Vietnam; canhnt@uel.edu.vn \\ 3 Faculty of Accounting \& Auditing, University of Economics and Law, Ho Chi Minh City, Vietnam \\ 4 Center for Economic and Financial Research, University of Economics and Law, Ho Chi Minh City, Vietnam \\ * Correspondence: liemnt@uel.edu.vn (N.T.L.); khuongnv@uel.edu.vn (N.V.K.)
}

Received: 28 June 2020; Accepted: 22 July 2020; Published: 24 July 2020

\begin{abstract}
The relationship with customers has important implications for operating decisions as well as firm performance. One important aspect of the supplier-buyer relationship is the contract duration, and how this factor is likely to affect firm investments has been under-researched. This study aims to investigate whether corporate innovation is linked to the maturity of contracts between suppliers and buyers. Using a sample of 1516 manufacturing firms in Vietnam for the period of 2014 to 2018, we find that longer-term contracts are positively related to firm propensity of innovation. However, only contracts with foreign purchasers have this characteristic, confirming the supportive role of foreign partners in uplifting the technology for domestic suppliers in a developing country. Interestingly, longer contracts do not tend to facilitate firm innovation or raise the aimed level of newness for firms with very long contracts compared with those that have short-term contracts. This is consistent with the agency cost theory. These findings are robust to different specifications and econometric approaches. Based on the findings, implications are provided to manage the relationship with customers more efficiently.
\end{abstract}

Keywords: contract length; firm innovation; agency cost theory; manufacturing firms

\section{Introduction}

There are different costs and benefits associated with contracts of various lengths between buyer and seller, and the choice can be challenging at times [1]. Long-term contracts facilitate the information exchanges between the two, allow the monitoring of production, and reducing costs embedded with frequent contract rebidding. Furthermore, long-term contracts are conducive to the mutual cooperation and efforts between the buyer and seller, which enhances the potential for the reduction in costs and time for product production [1]. Thanks to a long relationship with customers, the seller could receive more constant feedback and be able to identify trends, which is the prerequisite to innovation and to offering better services/products to the customer [2,3]. This is important as innovation is a complicated process that influences several types of stakeholders, and it can provide substantial benefits to upgrade the performance of both manufacturing and services firms [4-6].

Long-term contracts possess a clear advantage over short-term ones: risk-averse managers can demand a fixed price for a certain period under the contract in the context of high volatility in the market [1]. Nonetheless, contracts that specify such a condition tend to require a fixed investment beforehand. This type of investment can include the audit of the technical efficiency and financial ability of the supplier, and in certain cases require the buyer's aids in building up the technology and capital capacity to match the specific requirements of the buyer $[1,7]$. 
On the other hand, short-term contractual engagement can be preferred by risk-loving managers, as a speculative advantage is obtained by properly predicting the market price for the products or services. Furthermore, the seller can have the flexibility in approaching and offering the merchandise to other buyers, rather than having to commit to a fixed price in a specified period. As a result, Cohen [1] puts forward that managers need to weigh up the pros and cons between the advantages of hedging against price uncertainty and mutual cooperation that facilitates learning and better production efficiency attached to long-term contracts, and the flexibility and low upfront investments that short-term contracts offer.

Apart from the rationales related to operational optimization in the choice of contract length, the issue of agency cost can also matter. Feess et al. [8] argue that the agents could have different incentives and thus respond differently when faced with changes in the contract length. Expectedly, long-term contracts are prone to introduce the principal-agent problem. In the context of the buyer-seller relationship as discussed in this paper, the principal is the buyer while the seller is the agent contracted to perform the task of producing a product/service. Viewed under another perspective, the manager of the supplier firm (the agent) can receive the benefit of long-term contracts with the purchaser, reducing the incentive to innovate and destroying the firm owner's (the principal's) value. According to Sappington [9], the agent must be motivated to deliver excellent tasks as the principal would expect, because monitoring all the activities of the agent is not possible and prohibitively costly. Consistently, Kloyer et al. [10] are convinced that moral hazard can have a dragging effect on the efficiency of research and development, and Bao et al. [11] find that trust and contracts matter for the product innovation of manufacturers.

With regard to contract length-related literature, extant studies based on agency theory tend to examine the performance of the contracted athletes in sporting fields or managerial performance. Specifically, workers or athletes whose compensation and employment security are performance-based have a stronger incentive to exercise their full efforts $[8,12]$. This is no longer the case once job security or compensation does not depend on performance, and one of the situations is when the agent has obtained a long-term contract. The contract with longer coverage helps secure income, thus lowering the meaning of the agent's effort spent on the task. Moreover, workers can be less concerned about the employer assessment of their productivity when the contract maturity is long [13]. In the realm of corporate investment decisions, agency problems imply that once the seller firm has obtained a long-term contract that secures income in a competitive market, the incentive changes towards innovation in order to enhance production efficiency or towards making research and development expenditures to differentiate their products.

The motivation behind this study is to examine the principal-agent problem in the context of corporate innovation. Studies have found the formality level of contracts could affect the innovation efficiency [14]. In addition, the agency issue associated with the maturity of a contract has been excessively investigated with regard to the performance of athletes or workers or managers (the agents) when they are hired with long-term contracts by the owner of the club or firm (the principals), respectively. Nevertheless, the link between contract length and firm innovation between supplier and buyer has not been studied previously.

The remaining sections of the study include discussion on the relevant literature on the link between contract length and firm innovation. Section 3 details the research methodology where we build hypotheses and empirical strategies to test the hypotheses. Section 4 presents the empirical results and Section 5 concludes the paper with implications and directions for future studies.

\section{Literature Review and Hypothesis Development}

When engaging in a transaction, buyers and sellers are not only concerned about the identity of the partner, but also the length of the transaction. A simple model of the decision by seller and buyer in two periods can easily highlight the pros and cons of a long-term contract [15]. Trade is assumed to be efficient and beneficial in the first period, and what is unknown is the trade outcome 
in the second period. If trade is also efficient in the later period, a long-term contract should be put in place. On the other hand, if trade is inefficient afterwards, a short-term contract mandating trade only in the first period is better. Nonetheless, the outcome in the second period is uncertain, thus both short-term and long-term contracts are not likely to be optimal. This simple framework explains why a short-term or a long-term contract is not always efficient, and contract duration needs to vary case by case. Interestingly, MacLeod and Malcomson [16] and Segal [17] suggest that no contract can be as effective as a sophisticated contract.

\subsection{Contract Length and Firm Innovation}

Stable customers help enhance firm performance and value [18,19], and long-term contracts have various advantages over short-term ones. Long-term contracts facilitate more frequent information exchanges between the two parties and allow close monitoring of the production process. The idea that customers can support in generating ideas to improve the firm's products and services has been increasingly supported, and insights related to customer characteristics are essential to the design of products and services and to guide innovative activities [20,21]. Ko et al. [22] opine that competent customer relationship management can efficiently support firm innovation through the efficient extraction and handling of customer-related information. Porter [2] stresses that strong relationships with the buyer assist firms in exchanging information between the two, and once the customer-related information can flow without being barricaded, innovation is facilitated. Dubois and Vukina [23] cited a message from a company to its growers, stating that the firm believes that contracts with a longer maturity would improve the trust and knowledge between the firm and its growers. Through this case study and additional empirical tactics, Dubois and Vukina [23] empirically confirm that as growers have longer contracts, their incentives to invest in human capital and to innovate are higher.

Furthermore, with long-term contracts, the costs entwined with frequent contract rebidding caused by short-term contracts should be lower [1]. Several sorts of costs are specified when the buyer needs to re-choose a supplier upon the expiration of a short-term contract: the identification of new and potential sellers, negotiation, determination of the seller and contract finalization [24]. Due to information asymmetry in the market, the sellers themselves also need to exert effort to signal their quality to find buyers. Coase [25] suggests that long-term contracts are introduced to avoid such costs, and argues that a two-year contract can reduce such ex-ante expenses by half compared to two one-year contracts.

Additionally, mutual cooperation and efforts between the buyer and seller can be facilitated through long-term relationships through long-term contracts, which enhances the potential for the reduction in costs and time for product production. Reviewing a large body of literature explaining the role of long-term contracts, Halonen-Akatwijuka and Hart [15] come to the conclusion that contracts with a long maturity are associated with more relationship-specific investments. In turn, these relationship-specific investments are made to offer unique products to the need of the buyer, thus making it costly and infeasible for the buyer to switch to substitute products [26]. A number of studies including Tan et al. [27], Chu et al. [28], Nunn [29], Kale and Shahrur [30] claim that innovation is necessary to meet customer's specific needs. Thanks to a long relationship with customers, the seller is able to receive more constant feedback and be able to identify trends as guidelines to the innovation to offer better services/products to the customer. Su and Bao [31] find evidence suggesting that total specific investment exerts a positive impact on the performance of innovation collaboration.

Cohen [1] specifically emphasizes the supplier-buyer cooperation as well as the incentive for the learning of a supplier as the chief advantages of a long-term contractual engagement between the two. As for the outcome of supplier learning, the improvement rate needs to be higher than a threshold value to validate the cost of specific investments associated with long-term contracts. What complicates this is the fact that the threshold value depends on a number of critical factors, including the initial fixed investment outlay, the risk preference of the manager and the market price volatility [1]. For example, highly risk-averse managers tend to value the ability to protect the firm against price uncertainty, 
so they are more likely to be interested in long-term contracts even when the improvement rate is not high. Some researchers rely on a fixed cost assumption when writing a contract, and suggest a contract length chiefly by the level of uncertainty of the environment [32,33].

Pursuing a procurement bid, an efficient supplier with, perhaps, the lowest cost, is chosen, and a long-term contract is established to save the cost of frequent bids caused by shorter contracts. In a competitive market, shorter contracts allow the buyer to take speculative advantage and seek the current lowest-cost suppliers, thus reducing the price of inputs. Therefore, if transaction costs are not so high and the market is highly competitive, chances are the buyer would prefer to opt for short-term contract so that it can constantly switch to a new supplier with lowest-cost products at the moment [34]. In this market condition, long-term contracts can be highly valuable due to its ability to secure income stream for the supplier.

In a study by Baker et al. [35], it is expected that the economic uncertainty induced by Covid-19 is likely to lead to large output shrinkages. Especially, the economic uncertainty causes a huge cut in innovation-related expenditures as well as other expenses to improve the management capability, thus further undermining the productivity at least in the short-term future. Several studies point out that innovation projects tend to be risky and unpredictable, and are suitable in the long run. Innovation is an effort that requires huge financial resources, and unfortunately as opposed to other general investment, the cost of financing innovation activities is likely to be higher [36-38]. This is due to the uncertain outcomes associated with research and development activities; in other words, inputs are spent without guaranteed advantageous outcomes, and possibly end up being sunk costs for the firm. Furthermore, R\&D activities should be kept clandestine to ensure asset specificity [27]. Innovation activities are also found to lower earnings quality, exacerbating issues with information asymmetry [39]. Therefore, due to the riskiness, information asymmetry and uncertain outcomes associated with innovation activities, internal resources tend to be the main source for these activities $[40,41]$.

Barrero et al. [42] show that, since innovative investments are irreversible and present in intangible forms, they are extremely sensitive to a state of uncertainty. It can be expected that long-term contracts, which are valuable to risk-averse managers, can be conducive to firm investment in the R\&D compartment.

To summarize, in general, it is expected that long-term contracts have various advantages compared to short-term ones, and are more conducive to innovation. As a result, the following hypothesis is established:

Hypothesis 1 (H1). Long-term contracts have a positive association with firm innovation.

\subsection{Non-Linear Relationship Between Contract Length and Firm Innovation}

As mentioned earlier regarding the study of Cohen [1], there are conditions in which long-term contracts tend to be more favorable to firm innovation compared to short-term contracts. These are when the improvement rate and learning ability from long-term contracts are not high, and managers are quite risk-averse while market prices are volatile.

Diamond [43] believes that short-term contracts could be employed as a means to signal that the agent is of a high quality, and that it is willing to subject itself to regular renegotiations. This can also be explained using the agency theory: short-term contracts offer the buyers more flexibility to switch to other suppliers with better prices and services, so firms with high quality products at reasonable prices thanks to decent innovative capability are more confident in engaging in short-term contracts. On the contrary, firms that are less capable of maintaining competitive products due to inefficient investments in innovation or low a innovative effort may feel more safety in attaining a long-term contract with buyers.

Stiroh [13] finds that long contracts tend to undermine the importance of employer's assessment and perception of employee's ability; as a result, workers have been incentivized to work less hard once their contract is finalized. This is strongly consistent with the findings of Joskow [44] who finds 
that risk aversion can be considered as the most important factor for athletes to strive for long-term contracts. This is because with longer contracts, athletes are less worried about the risk of being fired following the deterioration of their performance, at least during their contracted period.

Long-term contracts are found to be connected to a moral hazard effect, which leads to a negative relationship between contract duration and athlete performance on average [8,12]. These studies suggest that effort levels of athletes under long-term contracts are lower than those in short-term ones. Enhancing contract duration has been considered as a tool to protect the interest of agents, thus increasing agency costs $[8,45]$.

Therefore, it is clear that long-term contracts offer several benefits, especially by offering investment and stable conditions for firms to invest in innovative activities. However, once the length of the contract is over a threshold, it is more likely to raise the agency cost, depriving the firm of the incentives to innovate. Too-long contracts tend to secure the firms from the surrounding uncertainty, restraining the firms from keeping pace with the development of technology. This pattern can be highly destructive in a competitive market where managers are required not to be entrenched and the costs of making inefficient decisions are high [46-49]. Overall, these arguments suggest a non-linear inverted U-shaped relationship between contract length and firm innovation.

Hypothesis 2 (H2). Contract length has a non-linear inverted U-shaped relationship with corporate innovation.

\section{Research Methodology}

This study seeks to void the gap of the link between contract length and firm innovation by employing data from surveys conducted by the General Office of Statistics on manufacturing firms in Vietnam during the period from 2014 to 2018. There are two datasets in the present study. The first dataset is on the general characteristics of the firms such as total assets, total debt and profitability. These general surveys were conducted on a large number of firms in each year, e.g., in 2014 over 400,000, while in 2018, over 600,000 firms. The second dataset provides information on the technology adoption by a fraction of the firms in the first dataset. The information contained covers several important aspects including the average duration of contracts with foreign customers and with domestic customers, and Research and Development expenditures and the number of technological adjustments during each year. The second dataset is obtained from the surveys specialized in the technology adoption on a sample of about 5000 firms out of a much larger number in the general surveys mentioned above. The two datasets are merged using a tax code as the key variable to obtain variables covering both general characteristics and technology adoption of manufacturing firms in Vietnam. Filtering missing observations leaves us with a final sample of 1516 manufacturing firms over the period of 2014-2018.

As for empirical models, we rely on the following model to investigate the impact of contract length on firm propensity to innovate:

$$
\log \left(\frac{p}{1-p}\right)=\beta_{1} \text { con_len }+\beta_{2} \text { size }+\beta_{3} \text { lev }+\beta_{4} \text { roa }+\beta_{5} \text { techtran }+\beta_{6} \text { export }+\beta_{7} \text { cust_no }
$$

where: inno is the response variable, receiving the value of 1 if the firm responds Yes to the question of whether it conducted research and development activities in the considered year, and 0 otherwise. $\mathrm{P}$ is the probability of innovation being conducted for given values of a vector of explanatory variables, or the probability of the inno variable receiving the value of 1 . Since the binary dependent variable (inno) has only two values, which are 0 and 1 , we employ logistic regression for panel data. This is because when the response variable is a binary variable, it is not appropriate to apply conventional Ordinary Least Squares (OLS) regression or other regression techniques that assume the distribution of the error term follows a normal one. Instead, logistic distribution is applied to ascertain the validity of the statistical inferences.

Con_len is the main explanatory variable of interest, measured by the average length of all the contracts with foreign customers (con_len_foreign) and domestic customers (con_len_domestic). Size is 
the firm size, measured by the natural logarithm of the firm's total assets [50]. Large firms tend to have more resources available for risky and resources-consuming activities like innovation. Lev represents firm leverage, measured by the ratio of total debt to total assets. Firms that engage in innovation activities are riskier, and a higher leverage could boost the firm' risk level; in other words, more debt can result in a firm's lowered incentive to conduct innovation. ROA indicates firm profitability, measured by the ratio of income to total assets [50]. Firms with a higher profitability can generate more internal resources that are supportive of innovation. Techtran is a dummy variable indicating whether most of the contracts with customers involve a technological transfer, receiving the value of 1 if Yes and 0 otherwise. Technology transfer from international partners is a critical source for technological spillover in developing countries [51]. Export is the percentage of the total sales that is exported. Trade can trigger technology spillovers [52] and the innovation of exporters can respond positively to the competition in the export markets [53]. Bauer et al. [54] show that to adapt to international markets, firms need an efficient product market development ability, or a strong innovation capability. However, exports can have a non-linear effect on a domestic firm's innovation [55]. Cust_no is the number of customers that buy the most important product of the firms. The concentration of a customer base could have a negative effect on a firm's R\&D investment [27].

Using panel logistic regression, we estimate the research model with con_len being the contract duration for both foreign customers and domestic customers, in order to find out whether the impact of contract length on the propensity to engage in innovation activities differs between the cases of foreign and domestic buyers. We seek to improve the robustness of the findings by replacing the variable of innovation by the number of successful technological adjustments where we apply a fixed effects model to estimate. In addition, we split the sample into different subsamples based on the contract duration to test the robustness of whether short- and long-term contracts can assert a different impact on firm innovation. Finally, we provide another robustness check by investigating the ability of contract length to raise the willingness to aim for a higher level of newness in innovation, as a test of the ability of contract duration in dealing with agency cost.

\section{Results and Discussions}

\subsection{Descriptive Statistics}

Table 1 provides descriptive statistics about the variables in the model. The inno variable has the average value of 0.089 , indicating that about $9 \%$ of the observations engaged in innovation. The variable of contract length for foreign customers (con_len_foreign) is about 6.5 months, while that for domestic customers (con_len_domestic) is 8.5 months. It should be noted that these values are derived by taking the average of all the observations in the sample. However, when separately calculating the average value for the firms that have foreign customers, the average contract length is 9.2. The size of the firms in the sample is much smaller than the listed ones in Vietnam, thus implying their constraints in accessing external funding sources. The leverage ratio is about 54 per cent, indicating a high debt ratio so firms could meet difficulty in borrowing more to finance innovation activities, while ROA is only $4.7 \%$, lower than that of the listed ones. About 11 per cent of the observations involved technology transfer associated with the contracts. The ratio of export to total sales is about above one third of the total sales. Finally, the average number of customers that buy the main product of the firm is 3.6. 
Table 1. Descriptive statistics.

\begin{tabular}{cccccc}
\hline Variable & Obs & Mean & Std. Dev. & Min & Max \\
\hline inno & 8552 & 0.089 & 0.285 & 0.000 & 1.000 \\
con_len_domestic & 8552 & 8.526 & 6.031 & 0.000 & 48.000 \\
con_len_foreign & 8552 & 6.447 & 6.752 & 0.000 & 80.000 \\
size & 8552 & 11.352 & 1.606 & 2.485 & 17.297 \\
lev & 8552 & 0.543 & 0.262 & 0.000 & 0.980 \\
roa & 8489 & 0.047 & 0.111 & -0.568 & 0.631 \\
techtran & 8503 & 0.107 & 0.309 & 0.000 & 1.000 \\
export & 8552 & 37.375 & 38.942 & 0.000 & 100.000 \\
cust_no & 8551 & 3.654 & 1.329 & 0.000 & 5.000 \\
\hline
\end{tabular}

Source: Author's calculation from research dataset.

Table 2 provides pairwise correlation coefficients of the variables in the model. Accordingly, both con_len_domestic and con_len_foreign have positive and significant coefficients with inno, suggesting that longer-term contracts tend to facilitate innovation activities. It should be noted that the coefficient and significance level of con_len_foreign are much higher than those of con_len_domestic, suggesting that while contract term has a positive effect on innovation, contract term with foreign customers tends to lead to more investment in research and development. Larger firms are more likely to conduct innovation, while more debt seems to put a barricade on this activity of the firms. $R O A$ has a positive and significant correlation on innovation, suggesting that more profitable firms are able to earmark more resources to innovate. More customers for the main product increase the propensity to innovate for the firms. Finally, firms with more share of revenue from export have less incentive to conduct innovation activities.

Table 2. Correlation matrix.

\begin{tabular}{cccccccccc}
\hline & Inno & Con1 & Con2 & Size & Lev & Roa & Techtran & Export & Cust_No \\
\hline inno & 1.000 & & & & & & & & \\
con1 & $0.021^{* *}$ & 1.000 & & & & & & & \\
con2 & $0.034^{* * *}$ & $0.231^{* * *}$ & 1.000 & & & & & \\
size & $0.129^{* * *}$ & $0.067^{* * *}$ & $0.252^{* * *}$ & 1.000 & & & & \\
lev & $-0.029^{* * *}$ & $-0.043^{* * *}$ & $-0.038^{* * *}$ & $0.065^{* * *}$ & 1.000 & & & \\
roa & $0.059^{* * *}$ & $0.088^{* * *}$ & $0.125^{* * *}$ & $0.221^{* * *}$ & $-0.240^{* * *}$ & 1.000 & & \\
techtran & $0.147^{* * *}$ & $0.045^{* * *}$ & $0.030^{* * *}$ & $0.093^{* * *}$ & 0.002 & 0.015 & 1.000 & & \\
export & $-0.044^{* * *}$ & $-0.217^{* * *}$ & $0.414^{* * *}$ & $0.176^{* * *}$ & $0.023^{* *}$ & -0.015 & $-0.034^{* * *}$ & 1.000 & \\
cust_no & $0.085^{* * *}$ & $0.131^{* * *}$ & $-0.069^{* * *}$ & $0.218^{* * *}$ & 0.007 & $0.093^{* * *}$ & $0.032^{* * *}$ & $-0.292^{* * *}$ & 1.000 \\
\hline
\end{tabular}

Source: Author's calculation from research dataset. The bolded numbers below are $p$-values. Con1 is con_len_domestic, and Con2 is con_len_foreign. Size represents the size of the firm; Lev is the ratio of total debt to total assets; ROA is the profitability measure of the firm; Techtran is a dummy variable indicating whether most of buyer-purchaser contracts involve technology transfer; Export is the ratio of export sales to total sales; Cust_no is the number of the customers that buy the firm's main products. * ${ }^{* *}$, and ${ }^{* * *}$ denote significance at $10 \%$, $5 \%$ and $1 \%$, respectively.

\subsection{Results and Discussion}

Table 3 presents the results of the panel logistic regression. Contract length for foreign customers is significantly and positively related to innovation activities. On the contrary, contract length for domestic buyers has an insignificant impact on the propensity of firms to innovate. Estimating the model with both of these variables also yields similar results, confirming the advantage of contract duration with foreign customers over domestic ones. The patterns are in line with Hypothesis 1, which suggests that longer maturity creates favorable conditions for firms to innovate. These results are consistent with the argument that in a competitive market, having secured the income stream for a period of time allows firms to have more resources to do research and upgrade technology, and long-term contracts also enable firms to extract insights from customers and continuous feedback, which effectively directs the innovation process [2]. Furthermore, innovation activities are costly 
and risky and have a high level of information asymmetry, lowering the ability to access external financing. Once long-term contracts are signed, the buyer could make some specific investment so that the supplier is able produce specific merchandise that matches the requirements of the buyer [15], and such investments can relieve the supplier's constraints and increase close collaborations [26].

Table 3. Contract length and firm innovation.

\begin{tabular}{|c|c|c|c|c|c|c|}
\hline Inno & Foreign & & Domestic & & Both & \\
\hline con_len_foreign & $\begin{array}{c}0.046 \\
(0.012)\end{array}$ & $* * *$ & & & $\begin{array}{c}0.053 \\
(0.013)\end{array}$ & $* * *$ \\
\hline con_len_domestic & & & $\begin{array}{l}-0.004 \\
(0.014)\end{array}$ & & $\begin{array}{l}-0.023 \\
(0.015)\end{array}$ & \\
\hline size & $\begin{array}{c}0.442 \\
(0.070)\end{array}$ & $* * *$ & $\begin{array}{c}0.478 \\
(0.069)\end{array}$ & $* * *$ & $\begin{array}{c}0.446 \\
(0.070)\end{array}$ & $* * *$ \\
\hline lev & $\begin{array}{c}-0.26 \\
(0.353)\end{array}$ & & $\begin{array}{l}-0.335 \\
(0.351)\end{array}$ & & $\begin{array}{l}-0.262 \\
(0.353)\end{array}$ & \\
\hline roa & $\begin{array}{c}0.383 \\
(0.792)\end{array}$ & & $\begin{array}{c}0.528 \\
(0.788)\end{array}$ & & $\begin{array}{c}0.411 \\
(0.793)\end{array}$ & \\
\hline techtran & $\begin{array}{c}1.795 \\
(0.213)\end{array}$ & $* * *$ & $\begin{array}{c}1.768 \\
(0.212)\end{array}$ & $* * *$ & $\begin{array}{c}1.802 \\
(0.213)\end{array}$ & $* * *$ \\
\hline export & $\begin{array}{l}-0.008 \\
(0.003)\end{array}$ & $* * *$ & $\begin{array}{l}-0.005 \\
(0.003)\end{array}$ & * & $\begin{array}{l}-0.009 \\
(0.003)\end{array}$ & $* * *$ \\
\hline cust_no & $\begin{array}{c}0.154 \\
(0.073)\end{array}$ & $* *$ & $\begin{array}{c}0.148 \\
(0.072)\end{array}$ & $* *$ & $\begin{array}{c}0.159 \\
(0.073)\end{array}$ & $* *$ \\
\hline _cons & $\begin{array}{c}-11.754 \\
(0.824)\end{array}$ & $* * *$ & $\begin{array}{c}-11.783 \\
(0.823)\end{array}$ & $* * *$ & $\begin{array}{c}-11.606 \\
(0.829)\end{array}$ & $* * *$ \\
\hline No of obs & 8442 & & 8442 & & 8442 & \\
\hline
\end{tabular}

Source: Author's calculation from research dataset. ${ }^{*}, * *$ and ${ }^{* * *}$ denote significance at $10 \%, 5 \%$ and $1 \%$, respectively.

One more interesting finding is that contracts with foreign customers appear to be more beneficial in terms of facilitating corporate innovation. This result is consistent with the view that in a developing economy with fledgling financial markets and inadequate institutions, firms have more difficulty in receiving funding for innovation activities, and that the technology sources coming from foreign direct investment (FDI) and foreign partners are essential to drive the innovation level [56,57]. Therefore, only long-term contracts with foreigners are prone to deliver a favorable effect on firm innovation.

We provide a robustness check to the result in Table 3 by replacing the dependent variable (inno) to represent the number of successful technological adjustments during the year. As the variable is not a binary one anymore, we rely on a fixed effects estimation technique. This variable can dictate the innovation effort of a firm through adjusting technology to match the new competitive conditions or corporate requirements. In Table 4 , it is clear that the results are the same for the sign and the significance of the variables of con_len_foreign and con_len_domestic. In particular, con_len_foreign has a positive and significant correlation with the number of successful adjustments. On the other hand, con_len_domestic is not significant. These results again confirm the advantage of long-term contracts with foreign buyers in lifting the ability to innovate, consistent with Oum et al. [56] and Bozic and Rajh [57]. 
Table 4. Contract length and the number of successful technological adjustments.

\begin{tabular}{|c|c|c|c|c|c|c|}
\hline No of Adjustments & Foreign & & Domestic & & Both & \\
\hline con_len_foreign & $\begin{array}{c}0.033 \\
(0.006)\end{array}$ & $* * *$ & & & $\begin{array}{c}0.034 \\
(0.006)\end{array}$ & $* * *$ \\
\hline con_len_domestic & & & $\begin{array}{c}0.003 \\
(0.006)\end{array}$ & & $\begin{array}{l}-0.002 \\
(0.006)\end{array}$ & \\
\hline size & $\begin{array}{l}-0.085 \\
(0.067)\end{array}$ & & $\begin{array}{l}-0.081 \\
(0.067)\end{array}$ & & $\begin{array}{l}-0.085 \\
(0.067)\end{array}$ & \\
\hline lev & $\begin{array}{c}0.188 \\
(0.145)\end{array}$ & & $\begin{array}{c}0.186 \\
(0.146)\end{array}$ & & $\begin{array}{c}0.189 \\
(0.145)\end{array}$ & \\
\hline roa & $\begin{array}{l}-0.022 \\
(0.279)\end{array}$ & & $\begin{array}{l}-0.02 \\
(0.280)\end{array}$ & & $\begin{array}{l}-0.021 \\
(0.279)\end{array}$ & \\
\hline techtran & $\begin{array}{c}0.248 \\
(0.098)\end{array}$ & $* *$ & $\begin{array}{c}0.245 \\
(0.098)\end{array}$ & $* *$ & $\begin{array}{c}0.249 \\
(0.098)\end{array}$ & $* *$ \\
\hline export & $\begin{array}{c}0.003 \\
(0.002)\end{array}$ & & $\begin{array}{c}0.006 \\
(0.002)\end{array}$ & $* * *$ & $\begin{array}{c}0.003 \\
(0.002)\end{array}$ & \\
\hline cust_no & $\begin{array}{c}0.058 \\
(0.034)\end{array}$ & * & $\begin{array}{c}0.06 \\
(0.034)\end{array}$ & * & $\begin{array}{c}0.058 \\
(0.034)\end{array}$ & * \\
\hline _cons & $\begin{array}{c}0.862 \\
(0.738)\end{array}$ & & $\begin{array}{c}0.892 \\
(0.742)\end{array}$ & & $\begin{array}{c}0.871 \\
(0.739)\end{array}$ & \\
\hline r2 & 0.013 & & 0.005 & & 0.013 & \\
\hline No of obs & 6371 & & 6371 & & 6371 & \\
\hline
\end{tabular}

Source: Author's calculation from research dataset. ${ }^{*}, * *$ and ${ }^{* * *}$ denote significance at $10 \%, 5 \%$ and $1 \%$, respectively.

We proceed with the test of Hypothesis 2 about the non-linear effect of contract duration on firm propensity to innovate. The research sample is split based on the median value of the contract duration for each type of customer (foreign or domestic). In Table 5, we see that again the longer contract duration with foreign buyers enhances the ability of the firm to innovate, while it is not so favorable in the case of domestic purchasers.

With regard to foreign partners, it is clear that the coefficient of con_len_foreign for firms with shorter-than-median duration contracts is much larger than for those with longer-than-median duration. Moreover, for domestic partners, the negative effect of a contract length on firm innovation only exists for firms with contracts of longer-than-median duration. These patterns clearly indicate that even though in general firm innovation propensity raises as contract length increases, firms with too-long contracts can have lower incentives to engage in research and development departments. This is consistent with the prediction under Hypothesis 2.

The less favorable impact of contract duration when firms have too long contracts is in line with the agency cost theory, which predicts that when agents have secured an income for a prolonged period, incentives to exert efforts in updating technology and improving efficiency are lower. Extant literature examining the influence of contract duration on athlete performance also supports the view that long-term contracts can undermine athlete performance, compared to short-term ones $[8,12,45]$. Long-term contracts have several merits over their short-term counterparts, including the feedback and insights from customers, relationship-specific investments that provide technology and financial support, and uncertainty mitigation which spurs innovation. Nonetheless, too-long contracts could shield firms from the risk of uncertainty and strong competition in the market, which may discourage firms from maintaining their innovation level. To some extent, the non-linear effect in this study also provides evidence in support of the signaling tool of short-term contracts [43]. 
Table 5. Impact of contract length and firm innovation-subsamples.

\begin{tabular}{|c|c|c|c|c|c|c|c|c|}
\hline inno & $\begin{array}{c}\text { Foreign } \\
\text { Buyer_Long } \\
\text { Contract }\end{array}$ & & $\begin{array}{c}\text { Foreign } \\
\text { Buyer_Short } \\
\text { Contract }\end{array}$ & & $\begin{array}{c}\text { Domestic } \\
\text { Buyer_Long } \\
\text { Contract }\end{array}$ & & $\begin{array}{c}\text { Domestic } \\
\text { Buyer_Short } \\
\text { Contract }\end{array}$ & \\
\hline con_len_foreign & $\begin{array}{c}0.048 \\
(0.017)\end{array}$ & $* * *$ & $\begin{array}{c}0.367 \\
(0.123)\end{array}$ & $* * *$ & & & & \\
\hline con_len_domestic & & & & & $\begin{array}{l}-0.064 \\
(0.035)\end{array}$ & * & $\begin{array}{l}-0.058 \\
(0.066)\end{array}$ & \\
\hline size & $\begin{array}{c}0.369 \\
(0.101)\end{array}$ & $* * *$ & $\begin{array}{c}0.453 \\
(0.101)\end{array}$ & $* * *$ & $\begin{array}{c}0.53 \\
(0.092)\end{array}$ & $* * *$ & $\begin{array}{c}0.454 \\
(0.111)\end{array}$ & $* * *$ \\
\hline lev & $\begin{array}{c}0.26 \\
(0.500)\end{array}$ & & $\begin{array}{l}-1.026 \\
(0.542)\end{array}$ & $*$ & $\begin{array}{c}0.233 \\
(0.476)\end{array}$ & & $\begin{array}{l}-0.992 \\
(0.565)\end{array}$ & $*$ \\
\hline roa & $\begin{array}{c}1.369 \\
(1.080)\end{array}$ & & $\begin{array}{l}-1.149 \\
(1.336)\end{array}$ & & $\begin{array}{c}1.782 \\
(1.041)\end{array}$ & * & $\begin{array}{l}-0.307 \\
(1.306)\end{array}$ & \\
\hline techtran & $\begin{array}{l}1.982 \\
(0.306)\end{array}$ & $* * *$ & $\begin{array}{c}2.172 \\
(0.344)\end{array}$ & $* * *$ & $\begin{array}{c}1.97 \\
(0.283)\end{array}$ & $* * *$ & $\begin{array}{c}1.793 \\
(0.384)\end{array}$ & $* * *$ \\
\hline export & $\begin{array}{l}-0.017 \\
(0.004)\end{array}$ & $* * *$ & $\begin{array}{l}-0.009 \\
(0.006)\end{array}$ & $*$ & $\begin{array}{c}0.001 \\
(0.004)\end{array}$ & & $\begin{array}{l}-0.011 \\
(0.004)\end{array}$ & $* * *$ \\
\hline cust_no & $\begin{array}{c}0.088 \\
(0.104)\end{array}$ & & $\begin{array}{c}0.24 \\
(0.112)\end{array}$ & $* *$ & $\begin{array}{c}0.322 \\
(0.101)\end{array}$ & $* * *$ & $\begin{array}{c}0.039 \\
(0.117)\end{array}$ & \\
\hline _cons & $\begin{array}{c}-11.163 \\
(1.280)\end{array}$ & $* * *$ & $\begin{array}{c}-12.541 \\
(1.147)\end{array}$ & $* * *$ & $\begin{array}{c}-13.079 \\
(1.224)\end{array}$ & $* * *$ & $\begin{array}{c}-10.665 \\
(1.285)\end{array}$ & $* * *$ \\
\hline No of obs & 4268 & & 4174 & & 4755 & & 3687 & \\
\hline
\end{tabular}

Source: Author's calculation from research dataset. ${ }^{*}, * *$ and ${ }^{* * *}$ denote significance at $10 \%, 5 \%$ and $1 \%$, respectively.

In Table 6, again we replace the inno variable by the variable indicating the number of successful technological adjustments, while keeping other settings the same as in Table 5. We apply a fixed effects model to estimate the effect of contract duration on firm innovation. There are two important similarities in the results between Tables 5 and 6. First, contract duration only has a positive effect with foreign purchasers. Second, for foreign buyers, contract duration only enhances firms' propensity to engage in technological upgrades when under a certain threshold. These results clearly support Hypothesis 2 and the agency cost theory.

Table 6. Impact of contract length on the number of successful adjustments-subsamples.

\begin{tabular}{|c|c|c|c|c|c|c|c|c|}
\hline \multirow{2}{*}{$\begin{array}{l}\text { No of Adjustments } \\
\text { Con_Len_Foreign }\end{array}$} & \multicolumn{2}{|c|}{$\begin{array}{c}\text { Foreign } \\
\text { Buyer_Long } \\
\text { Contract }\end{array}$} & \multicolumn{2}{|c|}{$\begin{array}{c}\text { Foreign } \\
\text { Buyer_Short } \\
\text { Contract }\end{array}$} & \multirow[t]{2}{*}{$\begin{array}{c}\text { Domestic } \\
\text { Buyer_Long } \\
\text { Contract }\end{array}$} & \multicolumn{2}{|c|}{$\begin{array}{c}\text { Domestic } \\
\text { Buyer_Short } \\
\text { Contract }\end{array}$} & \\
\hline & $\begin{array}{c}0.028 \\
(0.021)\end{array}$ & & $\begin{array}{c}0.788 \\
(0.123)\end{array}$ & $* * *$ & & & & \\
\hline con_len_domestic & & & & & $\begin{array}{l}-0.044 \\
(0.028)\end{array}$ & & $\begin{array}{c}0.067 \\
(0.071)\end{array}$ & \\
\hline size & $\begin{array}{c}0.597 \\
(0.121)\end{array}$ & $* * *$ & $\begin{array}{c}0.138 \\
(0.087)\end{array}$ & & $\begin{array}{c}0.435 \\
(0.097)\end{array}$ & $* * *$ & $\begin{array}{c}0.534 \\
(0.123)\end{array}$ & $* * *$ \\
\hline lev & $\begin{array}{c}0.782 \\
(0.538)\end{array}$ & & $\begin{array}{c}0.126 \\
(0.444)\end{array}$ & & $\begin{array}{c}0.561 \\
(0.469)\end{array}$ & & $\begin{array}{l}-0.638 \\
(0.587)\end{array}$ & \\
\hline roa & $\begin{array}{l}-0.264 \\
(1.138)\end{array}$ & & $\begin{array}{c}0.133 \\
(1.124)\end{array}$ & & $\begin{array}{c}0.439 \\
(1.073)\end{array}$ & & $\begin{array}{c}0.922 \\
(1.384)\end{array}$ & \\
\hline techtran & $\begin{array}{c}1.909 \\
(0.395)\end{array}$ & $* * *$ & $\begin{array}{l}1.345 \\
(0.321)\end{array}$ & $* * *$ & $\begin{array}{c}1.703 \\
(0.312)\end{array}$ & $* * *$ & $\begin{array}{l}1.836 \\
(0.506)\end{array}$ & $* * *$ \\
\hline export & $\begin{array}{l}-0.009 \\
(0.005)\end{array}$ & $* *$ & $\begin{array}{l}-0.005 \\
(0.005)\end{array}$ & & $\begin{array}{c}0.022 \\
(0.004)\end{array}$ & $* * *$ & $\begin{array}{c}0.004 \\
(0.005)\end{array}$ & \\
\hline cust_no & $\begin{array}{c}0.067 \\
(0.116)\end{array}$ & & $\begin{array}{c}0.231 \\
(0.096)\end{array}$ & $* *$ & $\begin{array}{c}0.2 \\
(0.100)\end{array}$ & $* *$ & $\begin{array}{c}0.129 \\
(0.135)\end{array}$ & \\
\hline _cons & $\begin{array}{c}-11.855 \\
(1.508)\end{array}$ & $* * *$ & $\begin{array}{l}-7.68 \\
(0.953)\end{array}$ & $* * *$ & $\begin{array}{c}-10.783 \\
(1.177)\end{array}$ & $* * *$ & $\begin{array}{c}-14.153 \\
(1.343)\end{array}$ & $* * *$ \\
\hline No of obs & 2750 & & 3621 & & 3470 & & 2901 & \\
\hline
\end{tabular}

Source: Author's calculation from research dataset. ${ }^{*}, * *$ and ${ }^{* * *}$ denote significance at $10 \%, 5 \%$ and $1 \%$, respectively. 
Table 7 provides our last specification investigating the potential benefit of contract duration under a certain threshold. We introduce the aimed level of newness as a proxy for innovation effort and find that only firms that have contracted with international buyers have more incentives to conduct radical innovations or upgrades that are not meant to be incremental. We use ordered logistic regression for panel data to estimate the model since the dependent variable has 3 values: 1 indicating the desire to create products/processes that are new at the firm level, 2 indicating the same item at the country level and 3 aiming at international level. The contract length with domestic purchasers does not impose a significant impact on firm desire to aim for a higher level of innovation newness.

Table 7. Contract length and the aimed level of newness.

\begin{tabular}{|c|c|c|c|c|c|c|c|c|}
\hline \multirow{2}{*}{$\begin{array}{l}\text { Level of Newness } \\
\text { con_len_foreign }\end{array}$} & \multicolumn{2}{|c|}{$\begin{array}{c}\text { Foreign } \\
\text { Buyer_Long } \\
\text { Contract }\end{array}$} & \multicolumn{2}{|c|}{$\begin{array}{c}\text { Foreign } \\
\text { Buyer_Short } \\
\text { Contract }\end{array}$} & \multicolumn{2}{|l|}{$\begin{array}{l}\text { Domestic } \\
\text { Buyer_Long } \\
\text { Contract }\end{array}$} & \multirow[t]{2}{*}{$\begin{array}{l}\text { Domestic } \\
\text { Buyer_Short } \\
\text { Contract }\end{array}$} & \\
\hline & $\begin{array}{c}0.071 \\
(0.027)\end{array}$ & $* * *$ & $\begin{array}{c}0.929 \\
(0.157)\end{array}$ & $* * *$ & & & & \\
\hline con_len_domestic & & & & & $\begin{array}{l}-0.020 \\
(0.041)\end{array}$ & & $\begin{array}{c}0.033 \\
(0.081)\end{array}$ & \\
\hline size & $\begin{array}{c}0.536 \\
(0.167)\end{array}$ & $* * *$ & $\begin{array}{c}0.578 \\
(0.129)\end{array}$ & $* * *$ & $\begin{array}{c}0.814 \\
(0.124)\end{array}$ & $* * *$ & $\begin{array}{c}0.546 \\
(0.134)\end{array}$ & $* * *$ \\
\hline lev & $\begin{array}{c}0.724 \\
(0.723)\end{array}$ & & $\begin{array}{l}-0.813 \\
(0.649)\end{array}$ & & $\begin{array}{c}0.272 \\
(0.585)\end{array}$ & & $\begin{array}{l}-0.845 \\
(0.648)\end{array}$ & \\
\hline roa & $\begin{array}{c}2.522 \\
(1.595)\end{array}$ & & $\begin{array}{l}-0.159 \\
(1.524)\end{array}$ & & $\begin{array}{l}3.206 \\
(1.345)\end{array}$ & $* *$ & $\begin{array}{c}0.145 \\
(1.499)\end{array}$ & \\
\hline techtran & $\begin{array}{c}1.977 \\
(0.443)\end{array}$ & $* * *$ & $\begin{array}{c}1.96 \\
(0.391)\end{array}$ & $* * *$ & $\begin{array}{c}1.463 \\
(0.341)\end{array}$ & $* * *$ & $\begin{array}{c}1.369 \\
(0.461)\end{array}$ & $* * *$ \\
\hline export & $\begin{array}{l}-0.033 \\
(0.006)\end{array}$ & $* * *$ & $\begin{array}{l}-0.012 \\
(0.007)\end{array}$ & * & $\begin{array}{c}0.014 \\
(0.005)\end{array}$ & $* * *$ & $\begin{array}{l}-0.005 \\
(0.005)\end{array}$ & \\
\hline _cons & $\begin{array}{l}132.032 \\
(37.622)\end{array}$ & $* * *$ & $\begin{array}{l}22.859 \\
(6.003)\end{array}$ & $* * *$ & $\begin{array}{l}37.492 \\
(8.930)\end{array}$ & $* * *$ & $\begin{array}{c}39.887 \\
(12.716)\end{array}$ & $* * *$ \\
\hline No of obs & 2071 & & 3347 & & 2891 & & 2527 & \\
\hline
\end{tabular}

Source: Author's calculation from research dataset. ${ }^{*}, *$ and ${ }^{* * *}$ denote significance at $10 \%, 5 \%$ and $1 \%$, respectively.

With regard to foreign buyers, contract length generally increases the motivation to innovate further and desire to create a radically new product/service/process. One particular noteworthy result is that longer contracts tend to have more impetus on firms to obtain radical innovation when under a certain threshold (under median duration in this study), as shown by the significantly lower coefficient in the sample with higher-than-median contracts compared to that of lower-than-median contracts. This further robustness check provides strong evidence to ascertain the more negative effect of contract length once over a certain threshold as a result of a potential agency issue.

\section{Conclusions and Discussion on Buyer-Supplier Contract Length and Open Innovation}

Previous literature has discussed the relationship between contracts and agents' performance, both at individual and corporate levels. The main focus of prior studies is on the link between contract duration and athletes' performance, and whether manager's contract duration affects firm investment and performance. Nonetheless, the relationship between the length of contract with buyers and firm innovation has not been dealt with, even though the several aspects of the link between customers and firms have been examined.

This study aims to void the gap by using data from the surveys conducted by General Office of Statistics in Vietnam for a period from 2014-2018, covering a wide range of financial indicators and technology adoption patterns. In the present article, we aim to investigate the impact of contract duration with (foreign and domestic) buyers on the firms' propensity to engage in innovation. The dependent variables indicate whether firms conducted research and development and the number of successful technological adjustments. 
Using logistic regression for panel data, we find that contracts with a longer term in general increase firm likelihood to perform innovation. This result is in line with the view that long-term contracts offer income security, promote more frequent feedback and information with customers and technology transfer and mutual collaboration. All of these commendable features create conditions conducive to technology upgrades and advancement. However, not all long-term contracts are beneficial to firm innovation, and only those with foreign buyers appear to be the sole driver for firms' technological updates. This result supports the argument that firms in developing countries tend to lack resources for risky and opaque innovation activities, thus the support and liaison with international corporations as buyers play an important role in encouraging supplier firms to do research. Previous literature only discusses the role of the participation of foreign partners in domestic firms' research and development, while the present paper provides evidence specifying one channel explaining that desirable effect: foreign partners, rather than domestic ones, are more capable of creating conditions for their suppliers to conduct innovative activities with their long-term contracts.

Furthermore, we find that longer term contracts do not always lead to a better incentive to innovate. The findings suggest that as the length of the contract surpasses a certain threshold, longer maturity of the contract is more likely to be associated with a higher agency cost, thus lowering the willingness to innovate. On the other hand, under a certain threshold, contract duration is positively related to firm innovation. This result is consistent with previous studies that focus on the negative link between contract duration and athlete performance, and extends the literature by examining this linkage in the context of corporate performance. This extension is important as the non-linear relationship has never been empirically examined before, while it should provide important implications for customer and investment management.

Open innovation can have complex effects on firm performance depending on a number of factors. Firstly, it may depend on how firms access knowledge from external channels. Chiang and Hung [58] suggest that open search depth, or utilizing knowledge from a restricted number of external sources, is bound to facilitate incremental innovation. On the other hand, open search breadth, or obtaining knowledge from a wide range of external sources, are more likely to trigger firms' radical innovations. This is consistent with the view of March [59], showing that broader knowledge searches may induce higher levels of exploratory organizational learning. For macro factors, Yun et al. [60] find that a global financial crisis can have a moderating effect on the link between open innovation and the performance of SMEs. Furthermore, Yun and Liu [61] point out the micro- and macro-dynamics of open innovation together with the changing roles of different stakeholders in sustainability matters.

In addition to the number and depth of the channels of external knowledge sources, the efficiency of open innovation may also be affected by the organizational modes. Bianchi et al. [62] find that different collaboration modes, e.g., licensing agreements and the provision of technical and scientific services, are used with different categories of partners (e.g., universities, product biotech companies). The effect of such complicated choices on firm performance provides potential venues for future studies.

Yun et al. [63] show that culture can be a critical driver of open innovation. According to this research, culture affects open innovation under different perspectives, namely entrepreneurship, intrapreneurship and organizational entrepreneurship. The authors point out that societies benefit from a culture that is cultivated for boosting open innovation; even for the public sector. Yun et al. [64] argue that a cooperation between governments and firms is needed to sustain conditions for open innovation in the market. To encourage a firm to participate in innovation, support in different forms need to be administered by the government.

Most SMEs are resource-constrained; therefore, they need to focus on their existing business to attain greater efficiency, thus being unable to diversify their businesses [65]. SMEs that lever on open innovation are able to access external resources of their open innovation partners, and this allows them to be engaged in diversification strategies. Nonetheless, Colombo et al. [66] opine that SMEs are not always willing as well as capable of utilizing an open innovation strategy, and this warrants further research on open innovation for SMEs. 
The implications of our study are two-fold. First, firms in developing countries can utilize the partnership with foreign purchasers to be able to learn and update the formers' technologies in a more effective manner. This study confirms the role of the access to external resources of innovation partners, but emphasizes more on the importance of international partners, rather than domestic ones. Extending Bianchi et al. [62], we provide insights into another cooperation mode, i.e., supplier-buyer relationships, that benefits firms in terms of innovative activities. Second, the study offers evidence that requires the management to be vigilant and to stay posted with the current technological development even when the firms have secured long-term contracts with the buyers. Long-term contracts provide security in terms of revenue, but in a competitive market, too much complacency from such contracts might put the firms at risk of having outdated technology. The above findings are robust to several specifications and econometric methods. These results again confirm the complication of the effect of open innovation on firm performance, which requires careful investigation of other channels to harness the negative points and promote positive points of open innovation.

The limitations in the paper are that we have not considered whether the governance characteristics of the firms can interfere with the relationship between contract length and firm open innovation, as well as whether the interaction between contract length and firm innovation can exert a significant impact on firm performance. Firm ownership and characteristics of board of directors are potential factors to study their moderating effect on the association between contract length and firms' research and development. Furthermore, the examination of the impact of contract duration and innovation on firm performance should provide evidence to check the robustness to this study, and offer a scientific base for corporate decision makers in terms of the management of customer relationship and innovation. Therefore, these should serve as highly potential venues for future research.

Author Contributions: Conceptualization, N.T.L.; Formal analysis, N.T.L. and N.V.K.; Writing—original draft, N.T.L. and N.V.K.; Writing - review and editing, N.T.L., N.V.K. and N.T.C. All authors have read and agreed to the published version of the manuscript.

Funding: This research was funded by Vietnam National University-Ho Chi Minh City (VNU-HCM) under grant number NCM2019-34-01. The APC was funded by Vietnam National University - Ho Chi Minh City (VNU-HCM).

Conflicts of Interest: The authors declare no conflict of interest.

\section{References}

1. Cohen, M.A.; Agrawal, N. An Analytical Comparison of Long and Short Term Contracts. IIE Trans. 1999, 31, 783-796. [CrossRef]

2. Porter, M.E. The Competitive Advantage of Nations. Harv. Bus. Rev. 1990, 68, 73-93.

3. Liu, P.-L.; Chen, W.-C.; Tsai, C.-H. An empirical study on the correlation between the knowledge management method and new product development strategy on product performance in Taiwan's industries. Technovation 2005, 25, 637-644. [CrossRef]

4. Canh, N.T.; Liem, N.T.; Thu, P.A.; Khuong, N.V. The Impact of Innovation on the Firm Performance and Corporate Social Responsibility of Vietnamese Manufacturing Firms. Sustainability 2019, 11, 3666. [CrossRef]

5. Kitsios, F.C.; Grigoroudis, E. Evaluating Service Innovation and Business Performance in Tourism: A Multicriteria Decision Analysis Approach; Management Decision; Emerald: Birmingham, UK, 2020.

6. Kitsios, F.; Kamariotou, M. Mapping new service development: A review and synthesis of literature. Serv. Ind. J. 2019, 40, 682-704. [CrossRef]

7. Haruvy, E.; Katok, E.; Ma, Z.; Sethi, S. Relationship-specific investment and hold-up problems in supply chains: Theory and experiments. Bus. Res. 2019, 12, 45-74. [CrossRef]

8. Feess, E.; Gerfin, M.; Muehlheusser, G. The Incentive Effects of Long-Term Contracts on Performance-Evidence from a Natural Experiment in European Soccer; Unpublished Manuscript; Frankfurt School of Finance and Management: Frankfurt, Germany; University of Bern: Bern, Switzerland; University of Bielefeld: Bielefeld, Germany, 2010.

9. Sappington, D.E. Incentives in Principal-Agent Relationships. J. Econ. Perspect. 1991, 5, 45-66. [CrossRef] 
10. Kloyer, M.; Helm, R.; Aust, C. Determinants of moral hazard in research and development supply relations: Empirical results beyond the agency-theory explanation. Manag. Decis. Econ. 2019, 40, 64-78. [CrossRef]

11. Bao, Y.; Li, Y.; Pang, C.; Bao, Y.; Yi, X. Do resource differences between manufacturers and suppliers help or hinder product innovation of manufacturers? The moderating role of trust and contracts. Ind. Mark. Manag. 2017, 64, 79-90. [CrossRef]

12. Falk, A.; Huffman, D.; MacLeod, W.B. Institutions and Contract Enforcement; National Bureau of Economic Research: Cambridge, MA, USA, 2008.

13. Stiroh, K.J. Playing for Keeps: Pay and Performance in The NBA. Econ. Inq. 2007, 45, 145-161. [CrossRef]

14. Stefan, I.; Bengtsson, L. Unravelling appropriability mechanisms and openness depth effects on firm performance across stages in the innovation process. Technol. Forecast. Soc. Chang. 2017, 120, 252-260. [CrossRef]

15. Halonen-Akatwijuka, M.; Hart, O. Short-Term, Long-Term, and Continuing Contracts; National Bureau of Economic Research: Cambridge, MA, USA, 2015.

16. MacLeod, W.B.; Malcomson, J.M. Investments, Holdup, and the Form of Market Contracts. Am. Econ. Rev. 1993, 83, 811-837.

17. Segal, I. Complexity and Renegotiation: A Foundation for Incomplete Contracts. Rev. Econ. Stud. 1999, 66, 57-82. [CrossRef]

18. Irvine, P.J.; Park, S.S.; Yildizhan, C. Customer-Base Concentration, Profitability, and the Relationship Life Cycle. Account. Rev. 2016, 91, 883-906. [CrossRef]

19. Patatoukas, P.N. Customer-base concentration: Implications for firm performance and capital markets: 2011 American accounting association competitive manuscript award winner. Account. Rev. 2012, 87, 363-392. [CrossRef]

20. Nambisan, S. Designing virtual customer environments for new product development: Toward a theory. Acad. Manag. Rev. 2002, 27, 392-413. [CrossRef]

21. Campbell, A.J.; Cooper, R.G. Do Customer Partnerships Improve New Product Success Rates? Ind. Mark. Manag. 1999, 28, 507-519. [CrossRef]

22. Ko, E.; Kim, S.H.; Kim, M.; Woo, J.Y. Organizational characteristics and the CRM adoption process. J. Bus. Res. 2008, 61, 65-74. [CrossRef]

23. Dubois, P.; Vukina, T. Incentives to Invest in Short-Term vs Long-Term Contracts: Theory and Evidence. BE J. Econ. Anal. Policy 2016, 16, 1239-1272. [CrossRef]

24. Coase, R.H. The Problem of Social Cost. In Classic Papers in Natural Resource Economics; Springer: London, UK, 1960; pp. 87-137.

25. Coase, R.H. The Nature of the Firm (1937); Origins, Evolution, and Development: New York, NY, USA; Oxford, UK, 1991; pp. 18-33.

26. Holmstrom, B.; Roberts, J. The boundaries of the firm revisited. J. Econ. Perspect. 1998, 12, 73-94. [CrossRef]

27. Tan, J.; Cao, H.; Kong, X. Do major customers promote firms' innovation? China J. Account. Res. 2019, 12, 209-229. [CrossRef]

28. Chu, Y.; Tian, X.; Wang, W. Corporate Innovation Along the Supply Chain. Manag. Sci. 2019, 65, $2445-2466$. [CrossRef]

29. Nunn, N. Relationship-Specificity, Incomplete Contracts, and the Pattern of Trade. Q. J. Econ. 2007, 122, 569-600. [CrossRef]

30. Kale, J.R.; Shahrur, H. Corporate capital structure and the characteristics of suppliers and customers. J. Financ. Econ. 2007, 83, 321-365. [CrossRef]

31. Su, Z.; Bao, Y. Invest Heavily and Symmetrically: The Impact of Specific Investment on the Performance of R\&D Collaboration. IEEE Trans. Eng. Manag. 2020, 67, 322-333. [CrossRef]

32. Gray, J.A. On Indexation and Contract Length. J. Political Econ. 1978, 86, 1-18. [CrossRef]

33. Dye, R.A. Optimal length of labor contracts. Int. Econ. Rev. 1985, 26, 251-270. [CrossRef]

34. MacKay, A. Contract Duration and the Costs of Market Transactions. SSRN. 2019. Available online: https://papers.ssrn.com/sol3/papers.cfm?abstract_id=3096534 (accessed on 25 June 2020).

35. Baker, S.; Bloom, N.; Davis, S.; Terry, S. COVID-Induced Economic Uncertainty and Its Consequences; VoxEU.org: London, UK, 2020.

36. Hall, B.H. The financing of research and development. Oxf. Rev. Econ. Policy 2002, 18, 35-51. [CrossRef] 
37. Czarnitzki, D.; Hottenrott, H. R\&D investment and financing constraints of small and medium-sized firms. Small Bus. Econ. 2011, 36, 65-83.

38. Mina, A.; Lahr, H.; Hughes, A. The demand and supply of external finance for innovative firms. Ind. Corp. Chang. 2013, 22, 869-901. [CrossRef]

39. Le, M.; Tran, T.; Ngo, T. Innovation and Earnings Management: A Bayesian Analytics of Listed Firms in Vietnam. SSRN. 2020. Available online: https://papers.ssrn.com/sol3/papers.cfm?abstract_id=3650257 (accessed on 25 June 2020).

40. Himmelberg, C.P.; Petersen, B.C. R \& D and Internal Finance: A Panel Study of Small Firms in High-Tech Industries. Rev. Econ. Stat. 1994, 76, 38-51.

41. Minton, B.A.; Schrand, C. The impact of cash flow volatility on discretionary investment and the costs of debt and equity financing. J. Financ. Econ. 1999, 54, 423-460. [CrossRef]

42. Barrero, J.M.; Bloom, N.; Wright, I. Short and Long Run Uncertainty; National Bureau of Economic Research: Cambridge, MA, USA, 2017.

43. Diamond, D.W. Debt Maturity Structure and Liquidity Risk. Q. J. Econ. 1991, 106, 709-737. [CrossRef]

44. Joskow, P.L. Contract duration and relationship-specific investments: Empirical evidence from coal markets. Am. Econ. Rev. 1987, 77, 168-185.

45. Aghion, P.; Bolton, P. Contracts as a Barrier to Entry. Am. Econ. Rev. 1987, 77, 388-401.

46. Giroud, X.; Mueller, H.M. Corporate Governance, Product Market Competition, and Equity Prices. J. Financ. 2011, 66, 563-600. [CrossRef]

47. Stigler, G.J. The Economies of Scale. J. Law Econ. 1958, 1, 54-71. [CrossRef]

48. Kim, E.H.; Lu, Y. CEO ownership, external governance, and risk-taking. J. Financ. Econ. 2011, 102, $272-292$. [CrossRef]

49. Li, M.; Lu, Y.; Phillips, G.M. CEOs and the Product Market: When are Powerful CEOs Beneficial? J. Financ. Quant. Anal. 2019, 54, 2295-2326. [CrossRef]

50. Zhou, B.; Li, Y.; Huang, S.; Guo, S.; Xue, B. Customer Concentration and Corporate Innovation: Effects of Financing Constraints and Managers' Expectation of Chinese Listed Companies. Sustainability 2019, 11, 2859. [CrossRef]

51. Ngo, Q.-T.; Doan, N.-P.; Tran, T.-H.T.; Nguyen, T.-D. Technology Adoption Strategies in the Supply Chain: The case of Vietnamese Young Small and Medium-sized Enterprises. J. Open Innov. Technol. Mark. Complex 2020, 6, 37. [CrossRef]

52. Keller, W. International trade, foreign direct investment, and technology spillovers. In Handbook of the Economics of Innovation; Elsevier: Amsterdam, The Netherlands, 2010; pp. 793-829.

53. Dai, M.; Yu, M.; Zhao, C. Export tightening, competition, and firm innovation: Evidence from the renminbi appreciation. Rev. Dev. Econ. 2017, 22, 263-286. [CrossRef]

54. Bauer, K.; Krinner, S.; Helm, R.; Raabe, K. Product Development Capabilities: Exploring Mediating and Moderating Links between International Product Adaptation and Industrial Manufacturers' Business Performance. Int. J. Innov. Manag. 2020, 24, 2050084. [CrossRef]

55. Chen, T.; Chen, X.; Wang, C.; Xiang, X. Export behavior and firm innovation: New method and evidence. Econ. Lett. 2018, 170, 76-78. [CrossRef]

56. Sothea, O.; Dionisius, N.; Harvie, C. Constraints, Determinants of SME Innovation, and the Role of Government Support. ERIA Discuss. Pap. Ser. 2014, 10, 1-38.

57. Božić, L.; Rajh, E. The factors constraining innovation performance of SMEs in Croatia. Econ. Res./Ekon. Istraživanja 2016, 29, 314-324. [CrossRef]

58. Chiang, Y.; Hung, K.-P. Exploring open search strategies and perceived innovation performance from the persective of inter-organizational knowledge flows. $R$ D Manag. 2010, 40, 292-299. [CrossRef]

59. March, J.G. Exploration and Exploitation in Organizational Learning. Organ. Sci. 1991, 2, 71-87. [CrossRef]

60. Yun, J.J.; Zhao, X.; Hahm, S.D. Harnessing the value of open innovation: Change in the moderating role of absorptive capability. Knowl. Manag. Res. Pr. 2018, 16, 305-314. [CrossRef]

61. Yun, J.J.; Liu, Z. Micro- and Macro-Dynamics of Open Innovation with a Quadruple-Helix Model. Sustainability 2019, 11, 3301. [CrossRef]

62. Bianchi, M.; Cavaliere, A.; Chiaroni, D.; Frattini, F.; Chiesa, V. Organisational modes for Open Innovation in the bio-pharmaceutical industry: An exploratory analysis. Technovation 2011, 31, 22-33. [CrossRef] 
63. Yun, J.J.; Zhao, X.; Jung, K.; Yigitcanlar, T. The Culture for Open Innovation Dynamics. Sustainability 2020, 12, 5076. [CrossRef]

64. Yun, J.J.; Won, D.; Park, K. Entrepreneurial cyclical dynamics of open innovation. J. Evol. Econ. 2018, 28, 1151-1174. [CrossRef]

65. Lynn, M.L. Patterns of Micro-Enterprise Diversification in Transitional Euroasian Economies. Int. Small Bus. J. 1998, 16, 34-49. [CrossRef]

66. Colombo, M.G.; Piva, E.; Rossi-Lamastra, C. Open innovation and within-industry diversification in small and medium enterprises: The case of open source software firms. Res. Policy 2014, 43, 891-902. [CrossRef] 